\title{
A Literature Review: The Used of PROSPER Model in Guidance and Counseling Services for Improving Students Mental Health
}

\author{
Kristiana Firdausi \\ Guidance and Counseling Program, Faculty of Teacher Training and Education \\ Sebelas Maret University Surakarta \\ kristianafirda.uns@gmail.com
}

\section{Article History}

accepted 01/11/2019

approved 11/11/2019

published 31/12/2019

\begin{abstract}
Internationally, in the past two decades, the issue of mental health has been the subject of discussion in the world health forum. Since 1946, at the International Health Conference, WHO released the definition of healthy humans as a condition in which an individual achieves "... not merely being free from disease, but capable of achieving physical, mental and social wellbeing." The definition has major consequences on the role of member states, including Indonesia, to put more effort in realizing the mental health of its people. One of the real efforts that can be done is to improve the mental health of students as the next generation of the nation, through guidance and counseling services based on the PROSPER model. The PROSPER model is a new scope in mental health, covering seven key elements that contribute to the realization of one's mental health namely: positivity, relationship, outcomes, strengths, purpose, engagement, and resilience. Guidance and Counseling teachers as promoters and students mental health facilitators, can integrate the PROSPER model in the program components that will be implemented. Thus, enriching content innovation regarding effective mental health, to realize smart and mentally healthy learners.
\end{abstract}

Keywords: PROSPER model, mental health, guidance and counseling

\section{Abstrak}

Secara internasional, dalam kurun waktu dua dekade terakhir, isu mengenai kesehatan mental menjadi perbincangan dalam forum kesehatan dunia. Sejak tahun 1946, dalam Konferensi Kesehatan Internasional, WHO merilis definisi manusia sehat sebagai kondisi dimana seorang individu mencapai "...tak sekedar bebas dari penyakit, melainkan mampu mencapai kesejahteraan fisik, mental, dan sosial." Definisi tersebut berkonsekuensi besar pada peran negara-negara anggota, termasuk Indonesia, untuk lebih berupaya mewujudkan kesehatan mental masyarakatnya. Salah satu upaya nyata yang dapat dilakukan adalah meningkatkan kesehatan mental peserta didik sebagai generasi penerus bangsa, melalui layanan bimbingan dan konseling (BK) berbasis model PROSPER. Model PROSPER merupakan ruang lingkup baru dalam kesehatan mental, mencakup tujuh elemen kunci yang berkontribusi dalam perwujudan kesehatan mental seseorang yakni: positivity, relationship, outcomes, strengths, purpose, engagement, dan resilience. Guru BK sebagai promotor dan fasilitator kesehatan mental peserta didik, dapat mengintegrasikan model PROSPER dalam komponen program BK yang akan diimplementasikan. Sehingga, memperkaya inovasi konten mengenai kesehatan mental yang efektif, untuk mewujudkan peserta didik yang cerdas dan sehat mental.

Kata kunci: Model PROSPER, kesehatan mental, bimbingan dan konseling

Social, Humanities, and Education Studies (SHEs): Conference Series https://jurnal.uns.ac.id/shes

p-ISSN 2620-9284

e-ISSN 2620-9292 


\section{PENDAHULUAN}

Secara global, masyarakat dunia memandang kesehatan sebagai prioritas yang utama, mengingat dampaknya pada fungsi seluruh aspek kehidupan. Tanpa kondisi yang sehat, seseorang tidak dapat melakukan fungsi dan perannya secara optimal. World Health Organization (WHO) (2004) menyatakan bahwa kesehatan merupakan keadaan sempurna seseorang baik dari segi fisik, mental, kesejahteraan sosial, dan bukan hanya bebas dari penyakit atau kecacatan saja. Definisi tersebut memperjelas perlunya perhatian khusus pada aspek kesehatan mental sebagai bagian dari aspek kesehatan secara utuh.

Kondisi manusia yang sehat mental, tidak hanya diartikan sebagai ketiadaan simptom-simptom psikopatologi, namun tercapainya keadaan well-being, dimana individu menyadari kemampuannya, mampu mengatasi situasi menekan dalam hidupnya, mampu bekerja secara produktif dan bermanfaat, serta mampu berkontribusi positif dalam masyarakatnya (WHO, 2004). Dari pernyataan tersebut, dapat diasumsikan bahwa kesehatan mental sangat berpengaruh bagi keberfungsian hidup seseorang, dan mendukung pencapaian kesejahteraan. Semiun (dalam Karyani \& Ali, 2017) mengungkapkan definisi kesehatan mental dari kalangan psikiater, yakni merupakan kondisi seseorang yang menguasai dan mengatasi segala perasaan dalam hidupnya sehingga tidak menimbulkan masalah mental.

Berdasarkan beberapa penjabaran diatas, dapat disimpulkan bahwa kesehatan mental merupakan keadaan dimana seseorang terbebas dari gangguan psikopatologis, serta mampu memfungsikan aspek kognitif dan afektifnya, sehingga dapat menghasilkan tingkah laku produktif yang mampu mengatasi tekanan, bekerja optimal, memaksimalkan potensi diri, beradaptasi dan berintegrasi dengan lingkungan sosialnya, serta berorientasi pada terwujudnya kondisi well-being dalam hidupnya.

Karakteristik seseorang yang memiliki kondisi sehat mental adalah: (1) mengenal dirinya dengan baik; (2) mengalami pertumbuhan, perkembangan, dan perwujudan diri dengan baik; (3) seimbang mentalnya, memiliki kesatuan pandangan, dan kebal terhadap stressor; (4) otonomi diri yang mencakup unsur-unsur pengatur kelakuan dari dalam atau kelakukan-kelakuan bebas berfungsi secara tepat; (5) realistis, bebas dari penyimpangan kebutuhan, dapat berempati, peka terhadap lingkungan sosial; (6) mampu beradaptasi dengan lingkungan dan berintegrasi dengan baik (Jahoda, dalam Karyani \& Ali, 2017).

Sayangnya, hingga saat ini masih muncul keprihatinan global mengenai kondisi kesehatan mental masyarakat dunia. Isu kesehatan mental yang marak beberapa tahun terakhir ini adalah banyaknya masalah kesehatan mental yang dialami oleh anak dan remaja. National Alliance on Mental IIIness (dalam Karyani \& Ali, 2017) mengungkapkan bahwa $50 \%$ permasalahan kesehatan mental permanen dimulai dari usia 14 tahun. Hasil Riset Kesehatan Dasar (Rikesdas) Kementerian Kesehatan Republik Indonesia (2015) juga mencatat bahwa pada tahun 2013 terdapat 6\% prevalensi gangguan mental emosional, seperti depresi dan kecemasan adalah remaja berusia 15 tahun ke atas. Faktor utama penyebab permasalahan kesehatan mental remaja sangatlah beragam, misalnya: kegagalan akademis di sekolah, konflik pertemanan, konflik dalam keluarga, serta situasi sosial seperti: kemiskinan (Freydenberg, dalam Karyani \& Ali, 2017). Jika tidak segera diatasi dengan tepat, permasalahan kesehatan mental remaja dapat berdampak lebih buruk, bahkan membuat individu melakukan tindakan berbahaya, seperti: melukai diri atau percobaan bunuh diri. Sebelum fenomena negatif tersebut terjadi, dapat dilakukan suatu upaya pencegahan, dengan menekankan kembali pentingnya promosi kesehatan mental di berbagai setting (William, Saxena, \& McQueen, dalam Karyani, 2016). Salah satu setting yang kondusif untuk mempromosikan kesehatan mental adalah setting persekolahan. 
Setting sekolah dianggap strategis karena: (1) sekolah merupakan lembaga yang sengaja diorientasikan untuk meningkatkan kualitas manusia; (2) berdasarkan beragam data hasil penelitian, anak usia sekolah yakni 6-18 tahun, membutuhkan perhatian dan bantuan khusus dalam peningkatan kesehatan mental; (3) hampir semua anak dan remaja menjalani kegiatannya di sekolah selama minimal 4-7 jam sehari; (4) anak-anak dan remaja yang ada di sekolah menjadi lebih mudah dijangkau karena berada dalam satu setting; (5) terdapat program bimbingan dan konseling di sekolah, yang dapat berperan penting sebagai promotor dan fasilitator kesehatan mental melalui implementasi layanannya (Wyn et al., Atkinson \& Hornby; Notoatmodjo; Miller; Nickerson, \& Jimerson; Karyani \& Ali, dalam Karyani, 2016).

Sekolah menjadi harapan untuk mencegah serta mengatasi masalah kesehatan mental anak dan remaja, sehingga perlu didesain sebagai sekolah yang mempromosikan kesehatan mental (WHO, 2005). Dalam konsep WHO, promosi kesehatan mental di sekolah dirancang menggunakan pendekatan whole school approach. Pendekatan whole school approach mengandung maksud dimana promosi kesehatan mental di sekolah tidak hanya menangani siswa yang mengalami masalah kesehatan mental, namun meningkatkan pula kapasitas positif siswa dan seluruh personel sekolah dalam mewujudkan well-being, serta adanya implementasi upaya kolaboratif dari seluruh komponen sekolah untuk menciptakan sekolah sebagai "institusi positif" yang mendukung kesehatan mental.

Pada ranah tersebut, program bimbingan dan konseling sebagai bagian integral dari keseluruhan program sekolah yang bertujuan memfasilitasi tercapainya seluruh aspek perkembangan siswa secara utuh (Permendikbud nomor 111, tahun 2014), dapat ikut serta berkontribusi positif untuk meningkatkan kesehatan mental siswa. Guru Bimbingan dan Konseling sebagai personel utama program BK, yang saat ini berkarya pada abad 21, harus memiliki kesadaran akan pentingnya kesehatan mental bagi peserta didik. Jika peserta didik memiliki kesehatan mental yang positif, maka perkembangan bidang pribadi, sosial, akademik, dan kariernya juga akan berjalan efektif (ASCA, 2015).

Empat komponen program bimbingan dan konseling (BK) komprehensif di sekolah yakni layanan dasar, layanan perencanaan individual, layanan responsif, serta dukungan sistem dapat dioptimalkan secara inovatif sesuai kebutuhan pada abad 21 untuk meningkatkan kesehatan mental peserta didik. Salah satu upaya inovatif yang dapat diselenggarakan adalah mengintegrasikan model PROSPER dalam implementasi layanan BK. Model PROSPER dijadikan sebagai acuan bagi guru BK untuk mengembangkan konten layanan terkait kesehatan mental dan membangun suasana positif yang mempromosikan kesehatan mental di sekolah. Sehingga, orientasi layanan BK tidak hanya pada aspek tugas perkembangan saja, namun juga mendukung pencapaian student well-being, yang berdampak positif pada perkembangan pribadi, sosial, akademis, dan karier.

PROSPER merupakan akronim sebuah konsep baru dalam lingkup kesehatan mental yang bertumpu pada pendekatan positive psychology, terdiri atas: positivity, relationship, outcomes, strengths, purpose, engagement, dan resilience. Ketujuh aspek tersebut merupakan elemen kunci yang berkontribusi dalam perwujudan kondisi wellbeing seseorang. Konsep ini dipandang relevan, untuk digunakan oleh guru BK dalam merancang penyampaian layanan BK serta inovasi konten layanan yang mempromosikan kesehatan mental peserta didik. Misalnya saja: dalam memberikan layanan dasar bagi siswa, terkait peningkatan keterampilan sosial, guru BK dapat, mengintegrasikan aspek positivity dalam konten layanan, sehingga memberikan kesadaran pada siswa bahwa positive emotions dan positive mindset perlu dikembangkan ketika berhubungan dengan orang lain. Selain itu, suasana positivity harus diciptakan guru BK ketika melakukan layanan konseling dan bimbingan bersama 
peserta didik, agar mendukung terwujudnya well-being secara positif. Dalam kajian literatur ini, penulis akan menyampaikan analisis kritis mengenai penggunaan model PROSPER dalam layanan BK guna meningkatkan kesehatan mental peserta didik di sekolah.

\section{Kemunculan Model PROSPER}

\section{PEMBAHASAN}

Pendekatan positive psychology mendasari munculnya konsep PROSPER dalam ranah kesehatan mental manusia. Psikologi positif berfokus pada pemunculan kondisi dan proses bernuansa positif untuk meningkatkan kesejahteraan hidup dan optimalisasi keberfungsian diri seseorang (McGrath \& Noble, 2015). Pendekatan ini mulai masif dikembangkan dalam setting pendidikan, mengingat pentingnya penciptaan suasana positif dan kondusif secara mental bagi peserta didik pada proses pembelajaran. Sejak tahun 2000, mulai muncul konsep-konsep psikologi positif yang menjadi tumpuan dalam mengimplementasikan strategi pembelajaran berbasis student well-being seperti Child-Friendly Educational Systems and Schools, Education for All (EFA), dan Focusing Resources for Effective School Health (FRESH) (Gunawan, Izzaty, \& Sanyata, 2019). Pada tahun 2015, Toni Noble dan Helen McGrath dari Australian Catholic University mengembangkan konsep baru mengenai pendekatan kesehatan mental dan student well-being yakni PROSPER.

Model PROSPER ini berisikan tujuh elemen kunci yang berkontribusi efektif dalam kesehatan mental seseorang yakni: positivity, relationship, outcomes, strengths, purpose, engagement, dan resilience. Validitas konstruk dari ketujuh elemen PROSPER telah diuji oleh 14 peneliti dan profesor dari Australian Catholic University (McGrath \& Nobel, 2015). Sebelumnya, mereka juga telah mengadakan wawancara dengan 54 pendidik, untuk mengumpulkan persepsi mengenai model PROSPER yang ditawarkan sebagai acuan meningkatkan kesehatan mental peserta didik. Dari 54 responden tersebut, diperoleh data sebagai berikut:

\begin{tabular}{|c|l|}
\hline PERSENTASE & \multicolumn{1}{|c|}{ PERNYATAAN } \\
\hline $\mathbf{1 0 0} \%$ & $\begin{array}{l}\text { Sangat setuju bahwa model PROSPER dapat membantu pendidik } \\
\text { mengidentifikasi konsep tentang student well-being dalam lingkup } \\
\text { persekolahan. }\end{array}$ \\
\hline $\mathbf{9 6} \%$ & $\begin{array}{l}\text { Sangat setuju bahwa dengan adanya model PROSPER (1) konsep } \\
\text { kunci mengenai kesehatan mental dapat mudah diingat; (2) para } \\
\text { pendidik menjadi mudah mengomunikasikan konsep kesehatan } \\
\text { mental kepada personel sekolah lainnya, karena akronim yang } \\
\text { dibuat relevan dengan makna. }\end{array}$ \\
\hline $\mathbf{9 0} \%$ & $\begin{array}{l}\text { Sangat setuju bahwa konsep PROSPER akan membantu para staff } \\
\text { untuk merefleksikan peran mereka dalam upaya meningkatkan } \\
\text { kesehatan mental siswa. }\end{array}$ \\
\hline $\begin{array}{l}\text { Sangat seuju bahwa konsep PROSPER memiliki potensi untuk } \\
\text { dikembangkan menjadi instrumen untuk mengevaluasi seberapa } \\
\text { baik capaian perwujudan sekolah berbasis kesehatan mental yang } \\
\text { sudah dilaksanakan selama ini. }\end{array}$ \\
\hline
\end{tabular}

Berdasarkan hasil yang dipaparkan diatas, maka sudah terbukti bahwa konsep PROSPER ini dibutuhkan dan dapat diaplikasikan dalam setting persekolahan oleh guru BK maupun personel pendidik lainnya. 


\section{Konsep Kunci Model PROSPER untuk Mewujudkan Student Well-Being}

Model PROSPER merupakan ruang lingkup yang dirumuskan oleh Toni Noble dan Helen McGrath (2015) untuk mengimplementasikan psikologi positif yang mendukung peningkatan kesehatan mental peserta didik, sehingga mampu mewujudkan kondisi students well-being. PROSPER merupakan sebuah akronim dari tujuh elemen kunci yang berkontribusi dalam kesejahteraan mental seseorang, ketujuh elemen tersebut adalah: positivity, relationship, outcomes, strength, purpose, engagement, dan resilience. Berikut rincian penjelasan dari ketujuh elemen tersebut:

Positivity. Secara sederhana didefinisikan sebagai kondisi seseorang dalam keadaan baik atau positif. Bagi peserta didik, positivity dapat diartikan sebagai keadaan dimana peserta didik mengalami emosi yang positif di sekolah seperti merasa aman, nyaman, dan bahagia. Kondisi positivity juga dapat diekspresikan oleh peserta didik dalam sikap apresiatif, saling menghargai, dan mindfulness.

Relationship. Dalam setting persekolahan, fokus dari aspek ini adalah adanya kondisi hubungan positif diantara sesama peserta didik, guru dengan peserta didik, staff sekolah dengan peserta didik dan guru, serta antara pihak sekolah dengan orang tua (McGrath \& Noble, 2015). Untuk mewujudkan kondisi tersebut, maka pendidik dan guru BK dapat membangun suasana positif untuk mengedukasi siswa mengenai nilainilai sosial pergaulan serta keterampilan-keterampilan sosial yang diperlukan dalam komunikasi dan interaksi di sekolah, keluarga, dan masyarakat.

Outcomes. Mengacu pada hasil yang dapat dicapai peserta didik meliputi: pencapaian tujuan yakni terwujudnya student well-being, pemahaman bahwa prestasi merupakan hasil kerja keras dan perjuangan, kedewasaan berpikir, dan kesadaran untuk mencapai optimalisasi diri serta berorientasi pada kesuksesan. Ketika peserta didik menerima penguatan positif dari hasil tersebut, maka hal ini akan berkontribusi positif dalam penguasaan kompetensi, proses belajar, dan pegembangan kondisi wellbeing dalam dirinya.

Strengths. Aspek ini didefinisikan sebagai cara berperilaku, berpikir atau merasa bahwa setiap individu memiliki potensi alami untuk sejahtera, yang memberikan kesempatan baginya untuk mencapai fungsi optimal dalam kehidupannya. Aspek dalam Strengths meliputi: pemahaman positif mengenai konsep diri, kapabilitas individu, dan pemahaman mengenai bagaimana mengaplikasikan kedua hal tersebut dalam konteks yang berbeda. Dalam layanan BK, sangat dimungkinkan terjadi aktivitas positif yang menjadi sarana peserta didik menaplikasikan strength dan potensi mereka secara optimal.

Purpose. Peserta didik akan lebih memaknai tujuan pembelajaran mereka, ketika mereka mengetahui bahwa tujuan yang akan dicapai berharga dan bermanfaat bagi kehidupannya. Memiliki tujuan dalam hidup, akan memberikan stimulasi positif bagi kesehatan mental peserta didik, memotivasi mereka untuk berupaya, dan menjadikan mereka pribadi yang mampu memaknai kehidupan secara positif. Para pendidik dan guru BK, dapat membantu peserta didik mengidentifikasi tujuan mereka, serta merancang secara spesifik untuk mencapai tujuan tersebut. Pengembangan keterampilan-keterampilan yang diperlukan juga harus diupayakan, misalnya: pengembangan keterampilan berpikir kritis, berkolaborasi, berempati, dan manajemen emosi diri.

Engagement. Dapat dimaknai sebagai keterlibatan positif peserta didik baik secara mental maupun perilaku dalam pembelajaran. Aspek ini menjadi prediktor yang baik untuk pencapaian hasil akademik peserta didik. Beberapa komponen dalam aspek keterlibatan yaitu: menikmati pembelajaran, menyukai proses pembelajaran, memiliki minat belajar, dan aktif terlibat dalam berbagai aktivitas belajar di sekolah. 
Resilience. Resiliensi tidak hanya mencakup kemampuan untuk bangkit dari keterpurukan atau kesulitan, dan berani menghadapi tantangan, tetapi juga mencakup keterampilan berpikir rasional, beradaptasi, memanfaatkan humor, bersikap optimis, dan mampu mencari bantuan secara tepat ketika dibutuhkan (Gunawan, Izzaty, \& Sanyata, 2019).

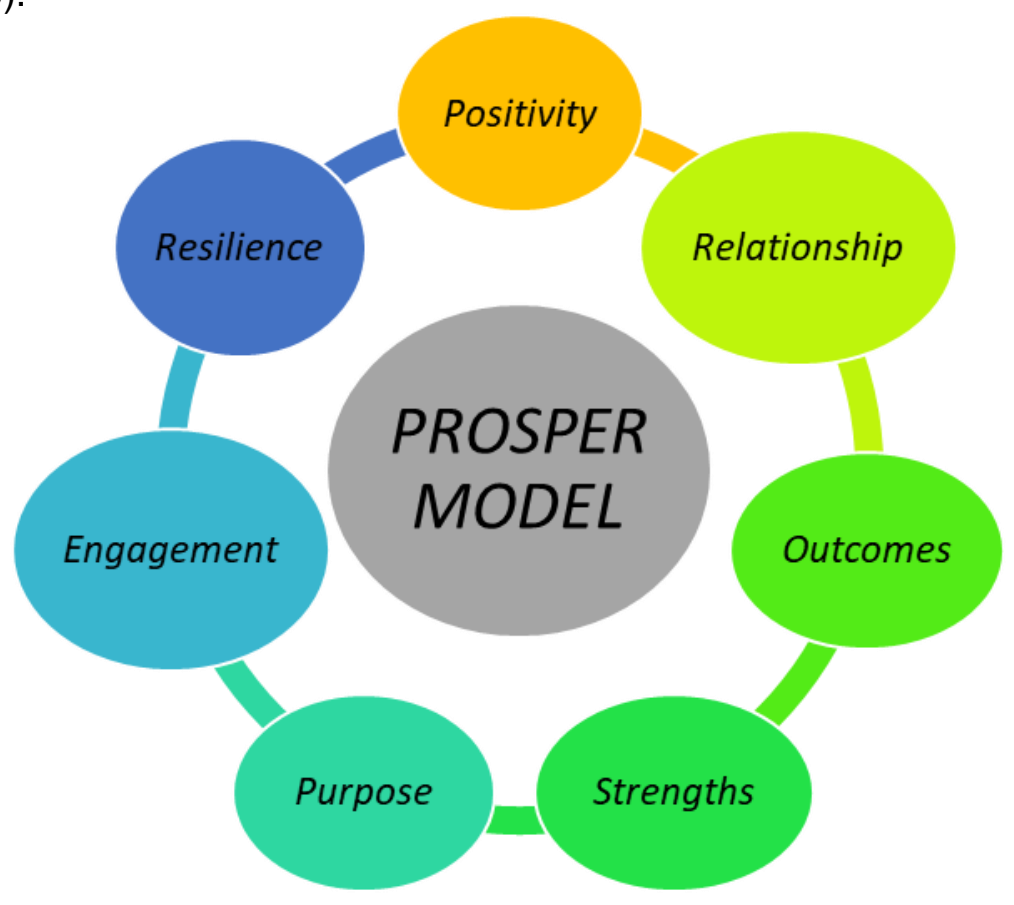

\section{Integrasi Model PROSPER dalam Komponen Program BK}

Guru BK secara spesifik dapat berkontribusi dalam peningkatan kesehatan mental peserta didik melalui implementasi empat komponen program BK dengan cara (ASCA, 2015):

1. Merancang layanan dasar program BK yang berfokus pada kesehatan mental peserta didik, mempromosikan tingkah laku positif, dan mampu menciptakan stigma positif terhadap kesehatan mental.

2. Menyediakan layanan responsif yang berorientasi pada student well-being, termasuk layanan konseling krisis yang berfokus pada intervensi kesehatan mental peserta didik, membantu peserta didik mewujudkan mental positif untuk belajar, dan mencapai kesuksesan perkembangan pribadi, sosial, akademik, dan kariernya.

3. Menyediakan layanan perencanaan individual bagi peserta didik yang berorientasi pada perencanaan akademik, karier masa depan, dan kematangan sosial-emosional peserta didik dengan mengintegrasikan aspek kesehatan mental.

4. Secara berkelanjutan mampu berupaya meng-update wawasan mengenai isuisu kesehatan mental peserta didik yang aktual dan mengembangkan layanan yang sesuai untuk mencegah serta mengatasi krisis kesehatan mental.

Model PROSPER yang relevan diterapkan dalam setting persekolahan dapat diiintegrasikan oleh guru BK untuk mengoptimalkan pemberian keempat komponen program layanan BK di sekolah yang berorientasi pada student well-being. Berikut rinciannya: 


\begin{tabular}{|c|c|}
\hline STRATEGI MODEL PROSPER & $\begin{array}{l}\text { IMPLEMENTASI DALAM KOMPONEN } \\
\text { PROGRAM BK }\end{array}$ \\
\hline $\begin{array}{l}\text { Encouraging Positivity } \\
\text { Mendukung peserta didik untuk } \\
\text { mengembangkan keterampilan } \\
\text { positif dan mewujudkan emosi } \\
\text { yang positif. }\end{array}$ & $\begin{array}{l}\text { 1) Layanan Dasar } \\
\text { Guru BK melakukan asesmen kebutuhan untuk } \\
\text { mengetahui keterampilan positif apa yang perlu } \\
\text { dikembangkan dalam diri peserta didik, } \\
\text { termasuk memanajemen emosi secara positif, } \\
\text { dan latihan pengekspresian emosi dan } \\
\text { perasaan secara positif. Hasil asesmen } \\
\text { kebutuhan tersebut kemudian ditindaklanjuti } \\
\text { dengan memberikan layanan bimbingan klasikal } \\
\text { atau bimbingan kelompok dengan konten materi } \\
\text { seperti manajemen emosi, pengekspresian } \\
\text { perasaan secara positif, belajar menghargai } \\
\text { sesame dan mengapresiasi karya orang lain. } \\
\text { 2) Layanan Perencanaan Individual: } \\
\text { Guru BK melaksanakan strategi layanan } \\
\text { bimbingan klasikal, bimbingan kelompok, } \\
\text { konseling kelompok, maupun konseling individu } \\
\text { yang membantu peserta didik memahami diri } \\
\text { secara lebih positif, mampu mengembangkan } \\
\text { keterampilan sosial dan mengatasi konflik } \\
\text { sosial, menemukan gaya belajar positif yang } \\
\text { tepat, dan mampu menemukan minat kariernya, } \\
\text { serta memahami kebutuhan untuk kebiasaan } \\
\text { bekerja yang positif. } \\
\text { Layanan Responsif } \\
\text { Memberikan layanan konseling individu atau } \\
\text { layanan konseling kelompok untuk mengatasi } \\
\text { krisis kesehatan mental peserta didik, dan } \\
\text { membantu peserta didik kembali memperoleh } \\
\text { kesehatan mental positifnya. Jika memang } \\
\text { diperlukan, guru BK dapat berkolaborasi } \\
\text { dengan psikolog dan ahli kesehatan mental, } \\
\text { bahkan referral, jika cakupan permasalahan } \\
\text { bersifat neurotis. } \\
\text { Dukungan Sistem Bu dapat mengadakan konsultasi, } \\
\text { Guru BK lainnya } \\
\text { kolaborasi dengan personel sekolah lainnya } \\
\text { untuk mewujudkan sekolah yang } \\
\text { mempromosikan kesehatan mental. Selain itu, } \\
\text { guru BK dapat memperkeaya wawasannya } \\
\text { mengenai pengembangan aspek positif peserta } \\
\text { didik baik dari aspek kognitif, sosial, afektif, dan } \\
\text { emosional. }\end{array}$ \\
\hline
\end{tabular}




\begin{tabular}{|c|c|}
\hline Building Relationship & \\
\hline $\begin{array}{l}\text { Mendukung peserta didik } \\
\text { mengembangkan keterampilan } \\
\text { sosial dan nilai-nilai sosial, yang } \\
\text { membangun interaksi sosial positif } \\
\text { di sekolah }\end{array}$ & $\begin{array}{l}\text { 1) Layanan Dasar } \\
\text { Guru BK dapat melaksanakan layanan } \\
\text { bimbingan klasikal dan bimbingan kelompok } \\
\text { yang bersifat informatif dan edukatif dengan } \\
\text { konten bertema pengembangan keterampilan } \\
\text { sosial dan nilai-nilai pergaulan sosial. } \\
\text { Guru BK mengaplikasikan beragam teknik } \\
\text { dalam bimbingan yang memberikan } \\
\text { kesempatan bagi peserta didik untuk melatih } \\
\text { keterampilan sosialnya dan membangun } \\
\text { suasana interaksi yang menggembirakan, } \\
\text { misalnya: teknik permainan simulasi, bermain } \\
\text { peran, sosiodrama, psikodrama. } \\
\text { 2) Layanan Responsif } \\
\text { Guru BK dapat melaksanakan strategi layanan } \\
\text { konseling individual atau konseling kelompok } \\
\text { untuk mengatasi permasalahan sosial peserta } \\
\text { didik yang menyebabkan krisis kesehatan } \\
\text { mental misal: penanganan trauma karena } \\
\text { mendapat perundungan. } \\
\text { 3) Dukungan Sistem } \\
\text { Guru BK melakukan upaya kolaboratif dengan } \\
\text { personel sekolah lainnya, seperti guru mapel, } \\
\text { wali kelas, wali murid, dan para staff untuk } \\
\text { mencapai komotmen bersama membangun } \\
\text { suasana hubungan positif di sekolah yang } \\
\text { mendukung kondisi well-being peserta didik. } \\
\text { Hubungan positif yang tercipta haruslah } \\
\text { mencakup hubungan diantara sesama siswa, } \\
\text { antara guru dengan siswa, antara staff dengan } \\
\text { siswa, dan antara pihak sekolah dengan orang } \\
\text { tua. }\end{array}$ \\
\hline $\begin{array}{l}\text { Facilitating Outcomes } \\
\text { Menciptakan lingkungan belajar } \\
\text { yang kondusif dan kesempatan } \\
\text { bagi peserta didik untuk } \\
\text { mempelajari keterampilan khusus } \\
\text { guna mencapai kesuksesan. }\end{array}$ & $\begin{array}{l}\text { Komponen program BK yakni layanan dasar, } \\
\text { layanan perencanaan individual, layanan responsif, } \\
\text { hendaknya senantiasa merancang penyampaian } \\
\text { layanan yang berorientasi pada perwujudan } \\
\text { lingkungan belajar yang positif. } \\
\text { Sehingga, peserta didik akan merasa difasilitasi } \\
\text { untuk mencapai hasil yang optimal dalam } \\
\text { perkembangan pribadi, sosial, akademik, karir, } \\
\text { serta mental emosionalnya. } \\
\text { Hal ini akan mendukung terbentuknya pribadi } \\
\text { akademis yang cerdas dan sehat mental. }\end{array}$ \\
\hline $\begin{array}{l}\text { Focusing on Strengths } \\
\text { Optimalisasi potensi peserta didik } \\
\text { dalam suasana mental yang } \\
\text { positif. }\end{array}$ & $\begin{array}{l}\text { Dalam mengimplementasikan layanan dasar dan } \\
\text { layanan perencanaan individual dengan strategi } \\
\text { layanan bimbingan klasikal ataupun bimbingan } \\
\text { kelompok, digunakan strategi yang bersifat student } \\
\text { centered, memberikan ruang bagi optimalisasi } \\
\text { potensi peserta didik, misal: bakat dan kemampuan } \\
\text { berbicara melalui diskusi kelompok. }\end{array}$ \\
\hline
\end{tabular}




\begin{tabular}{|c|c|}
\hline & $\begin{array}{l}\text { Khusus pada layanan perencanaan karier siswa, } \\
\text { guru BK harus melakukan asesmen mengenai } \\
\text { potensi dan bakat peserta didik agar bisa diarahkan } \\
\text { dalam pemilihan karier yang tepat dan sesuai } \\
\text { dengan minat siswa. }\end{array}$ \\
\hline $\begin{array}{l}\text { Fostering a Sense of Purposes } \\
\text { Mendukung peserta didik untuk } \\
\text { memaknai tujuan dan } \\
\text { kehidupannya. }\end{array}$ & $\begin{array}{l}\text { Guru BK memberikan layanan informatif dan } \\
\text { edukatif dengan konten yang terkait dengan } \\
\text { peningkatan pemaknaan kehidupan, misalnya: } \\
\text { mengembangkan kebiasaan bersyukur, berpikir } \\
\text { positif, dan fokus pada pencapaian kesuksesan. } \\
\text { Konten tersebut dapat dimasukkan dalam layanan } \\
\text { dasar dengan strategi bimbingan klasikal atau } \\
\text { bimbingan kelompok. Termasuk, dalam layanan } \\
\text { responsif untuk membantu peserta didik kembali } \\
\text { optimis dalam menjalani hidup, setelah mengalami } \\
\text { krisis, dan berupaya menata kembali kehidupan ke } \\
\text { arah well-being. }\end{array}$ \\
\hline $\begin{array}{l}\text { Enhancing Engagement } \\
\text { Menyediakan layanan yang } \\
\text { terbuka terhadap keterlibatan aktif } \\
\text { peserta didik dalam berbagai } \\
\text { aktivitas belajar. }\end{array}$ & $\begin{array}{l}\text { Dalam pelaksanaan layanan dasar, layanan } \\
\text { perencanaan individual, dan layanan responsif, } \\
\text { guru BK hendaknya membuka lebar keterlibatan } \\
\text { peserta didik untuk turut mengeksplorasi masalah, } \\
\text { menemukan solusi, dan secara mandiri } \\
\text { berkomitmen mengembangkan kebiasan-kebiasaan } \\
\text { positif dalam hidupnya. }\end{array}$ \\
\hline $\begin{array}{l}\text { Teaching Resilience } \\
\text { Mengedukasikan dan } \\
\text { mengembangkan resiliensi diri } \\
\text { positif pada peserta didik. }\end{array}$ & $\begin{array}{l}\text { Aspek resiliensi sangat relevan disampaikan secara } \\
\text { informative melalui layanan dasar dengan strategi } \\
\text { layanan bimbingan kelompok atau bimbingan } \\
\text { klasikal. } \\
\text { Selain itu, dapat pula menjadi salah satu solusi dan } \\
\text { komitmen untuk dikembangkan individu ketika } \\
\text { terlibat dalam layanan konseling yang bersifat } \\
\text { responsif, karena kepemilikan resiliensi ini } \\
\text { mengembangkan kemampuan individu untuk } \\
\text { bertahan dari situasi sulit, hidup lebih optomis, dan } \\
\text { memanajemen diri secara efektif. }\end{array}$ \\
\hline
\end{tabular}

\section{SIMPULAN}

Guru Bimbingan dan Konseling (BK) memiliki peran dan tanggung jawab untuk merancang dan mengimplementasikan komponen program layanan BK di sekolah, yang berorientasi pada optimalisasi perkembangan peserta didik secara utuh, sehingga mendukung pencapaian kesuksesan dalam kehidupannya. Saat ini, orientasi BK sebagai helping relationship tidak hanya berfokus pada tugas perkembangan peserta didik saja, namun mulai menaruh perhatian pada peningkatan kesehatan mental peserta didik, yang mendukung terwujudnya kondisi student well-being.

Guru BK pada abad 21, hendaknya memiliki kesadaran bahwa kesehatan mental merupakan aspek penting yang harus dimiliki peserta didik, di tengah kompleksitas tekanan (stressor) dan permasalahan di era sekarang. Berbekal keadaan mental yang sehat, aspek pribadi, sosial, akademis, dan karier peserta didik juga akan berkembang secara efektif. Oleh karena itu, guru BK harus memulai langkah nyata inovatif dalam implementasi layanan, dengan mengintegrasikan model PROSPER dalam layanan BK untuk meningkatkan kesehatan mental peserta didik. 
Model PROSPER menyediakan konsep komprehensif tentang tujuh elemen kunci yang berkontribusi dalam perwujudan well-being pada diri siswa. Model PROSPER akan membantu guru BK merancang penyampaian layanan dan konten layanan yang mempromosikan kesehatan mental peserta didik, dan membantu mereka mencapai kualitas hidup, kesuksesan, dan kesejahteraan. Penulis juga menyarankan agar di kemudian hari terdapat pengembangan keilmuan teoritis dan aplikatif dalam ranah $\mathrm{BK}$, yang berorientasi pada peningkatan kesehatan mental peserta didik, sebagai aspek penting dalam kesejahteraan hidup manusia.

\section{DAFTAR PUSTAKA}

ASCA, (2015). The School Counselor and Student Mental Health, diperoleh dari www.schoolcounselor.org

Gunawan, Izzaty, \& Sanyata, (2019). Exploring the Concept of School Mental Health Based on the PROSPER Model. Conference Paper on International Conference on Meaningful Education, 2019, KnE Social Sciences.

Karyani, (2016). Merancang Perubahan di Sekolah untuk Menjadi Sekolah yang Mempromosikan Kesehatan Mental, Jurnal Indigenous, 1 (1) 48-60.

Karyani, U. \& Ali, Q. (2017). Identifikasi Jenis Layanan BK dalam Upaya Menjaga dan Meningkatkan Kesehatan Mental Siswa. Prosiding SEMNAS Penguatan Individu di Era Revolusi Informasi, Universitas Muhammadiyah Surakarta.

Kementerian Kesehatan Republik Indonesia, (2015). Hasil Riset Kesehatan Dasar. Diakses pada tanggal 27 Oktober 2019 melalui http://www.depkes.go.id/resources/download/general/Hasil\%20Riskesdas\%2020 13.pdf/

McGrath, H. \& Noble, T. (2015). PROSPER: A new Framework for Positive Education, Springer Open Journal, Psychology of Well-Being, 5 (2) 1-17.

World Health Organization, (2004). Preventive Of Mental Disorder: Effective Intervention And Policy Options. WHO Summary Report. Diakses dari http://www.who.int/mental health/evidence/an/prevention of mentaldisorder sr/

World Health Organization, (2005). Promoting mental health: concepts, emerging evidence, practice: A Report of the World Health Organization Department of Mental Health and Substance Abuse in collaboration with the Victorian Health Promotion Foundation and The University of Melbourne. Diunduh dari http://www.who.int/mental health/evidence/MH Promotion Book.pdf/ 